\title{
Refrigeration Requirements for Precooling and Fermentation Control in Wine Making
}

\author{
J.M.W. le Roux ${ }^{\mathrm{a}}$, Katy Purchas ${ }^{\mathrm{b}}$, and B. Nell ${ }^{\mathrm{c}}$ \\ (a) Stellenbosch Farmers Winery, P.O. Box 46, Stellenbosch, 7600, RSA \\ (b) Undergraduate student, Department Chemical Engineering, University of Exeter, Devon \\ (c) Stellenbosch Farmers Winery. P.O. Box 46, Stellenbosch, 7600, RSA
}

Submitted for publication: November 1985

Accepted for publication: February 1986

Keywords: Refrigeration, precooling, wine making.

\begin{abstract}
A database is provided which can be used as a guide to determine the maximum refrigeration capacity required during wine making (precooling and fermentation control). Factors such as maximum daily grape intake, temperature of the grapes, precooling period, fermentation rate, heat gain in the fermentation building, heat gain in the refrigerated water distribution system as well as the efficiency of refrigeration systems are considered. Graphs, as well as equations, are provided from which the maximum refrigeration capacity required for grape intakes varying from $25 \mathrm{t}-$ $1000 \mathrm{t}$ per day can be determined in $\mathrm{kJ} / \mathrm{h}$. Provision is made for three different precooling periods. Separate graphs are provided from which the influence of the temperature of the grapes, as well as the influence of heat gain in refrigerated water distribution systems on the overall refrigeration capacity required, can be determined respectively. The database cannot replace thorough detailed refrigeration system design and engineering. However, it provides wine makers with a simple guide whereby designs can be checked, or the use of the capacity of existing systems managed more effectively.
\end{abstract}

Vergunst (1971) determined the refrigeration capacity required for a winery with a daily juice intake $(5 \mathrm{~d} /$ week $)$ of $171450 \mathrm{l}$, precooling from $26^{\circ} \mathrm{C}-15^{\circ} \mathrm{C}$ over a 22 hour period and fermenting from $22^{\circ}$ Balling to dryness within 6 days $\left(3.6^{\circ} \mathrm{B} \cdot \mathrm{d}^{-1}\right)$. For calculation purposes, Vergunst assumed a heat gain of $15 \%$. Unfortunately, it is difficult to use these figures as a basis from which to calculate the refrigeration capacities required for wineries where conditions differ from those used in this example.

The calculation of load and the determination of heat gain (refrigeration loss) under varying conditions are critical for the correct sizing of new refrigeration plants, as well as for the efficient management of the refrigeration capacity of existing plants. Factors such as maximum daily grape intake, temperature of the grapes, length of precooling period, fermentation rate, heat gain in the refrigerated water distribution system, heat gain in buildings or tanks and the efficiency of the refrigeration system are important. However, very little information correlating these factors is available.

The object of this paper is to provide a simple but effective database which can be used as a guide to determine the maximum refrigeration capacity required during wine making (precooling and fermentation control). A cellar crushing a total of $10000 \mathrm{t}$ of grapes over a period of two months (40 working days), does not crush $10000 / 40=250 \mathrm{t} /$ day. Invariably a peak is experienced during which 500-600 t may be crushed daily.

The data presented in this paper is specifically aimed at peak load conditions.

The authors would like to stress the point that this database does not and cannot replace thorough detailed refrigeration system design and engineering. However, they are of the opinion that it provides wine makers with a guide whereby designs can be checked, or the use of the capacity of existing systems managed more efficiently.

\section{METHODS}

\section{Assumptions:}

The following assumptions were made in establishing the database:

- 1 metric ton $(\mathrm{t})$ of grapes produces $800 l$ of juice of which $720 l$ affect the refrigeration load.

- sugar content of the grapes is $22^{\circ} \mathrm{B}$.

- density $(\rho)$ of the juice is $1,08 \mathrm{~kg} . \mathrm{l}^{-1}$

- specific heat of juice (Cp) is $3,64 \mathrm{~kJ} . \mathrm{kg} .{ }^{-1} \mathrm{~K}^{-1}$

- average temperature of the grapes is $22^{\circ} \mathrm{C}$.

- juice is precooled to $13^{\circ} \mathrm{C}$.

- juice ferments at a rate of $2^{\circ} \mathrm{B} .24 \mathrm{~h}^{-1}$ (i.e. 11 days fermentation period).

- heat of fermentation $\left(\triangle \mathrm{H}_{\mathrm{f}}\right)$ is $555 \mathrm{~kJ} . \mathrm{kg}^{-1}$ sugar.

- the refrigerated water system is designed to operate from $7^{\circ} \mathrm{C}$ to $13^{\circ} \mathrm{C}$.

- heat gain in buildings is $10 \%$ of the fermentation load.

-. heat gain in refrigerated water distribution piping is $20 \%$ of overall refrigeration load.

- refrigeration systems are $90 \%$ efficient.

$-\mathrm{K}=$ Kelvin.

\section{Refrigeration system model:}

The basic refrigeration system to which the data is applicable is schematically presented in Figure 1.

There are two sub-systems: A primary system, consisting of a compressor, condenser and water chiller, and a secondary system consisting of hot and cold wells and refrigerated water distribution pumps and piping.

\section{Precooling:}

The maximum precooling load $\left(\mathrm{Q}_{\text {mix }}\right)$ can be calculated as follows:

$\mathrm{Q}_{\max }=\mathrm{N}_{\max } \cdot \rho \cdot \mathrm{Cp} \cdot \triangle \mathrm{T}$ eq. 1 where $\mathrm{N}_{\max }=$ maximum rate of juice supply in $l \cdot \mathrm{h}^{-1}$

$$
\rho=1,08 \mathrm{~kg} \cdot .^{-1}
$$




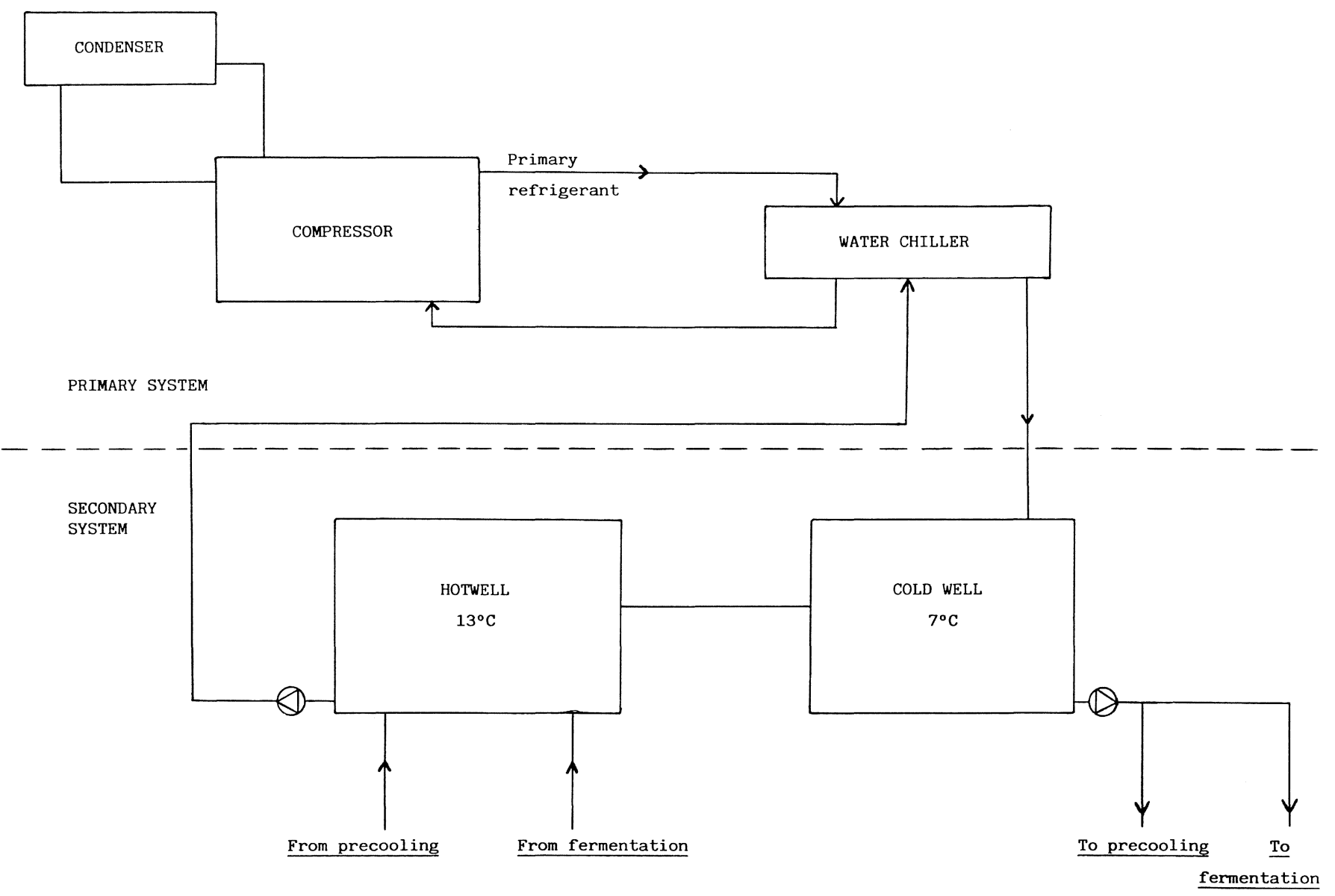

FIG. 1

$\mathrm{Cp}=3,64 \mathrm{~kJ} \cdot \mathrm{kg}^{-1} \cdot \mathrm{K}^{-1}$

$\triangle \mathrm{T}=$ Temperature difference

(Temperature of incoming juice minus the temperature to which the juice is precooled. In this model $\left.22^{\circ} \mathrm{C}-13^{\circ} \mathrm{C}=9 \mathrm{~K}\right)$.

For any given maximum daily grape intake (in $\mathrm{t}$ ), the maximum rate of juice supply $\left(\mathrm{N}_{\max }\right)$ will vary according to the length of the precooling period. From the equation given for determining the maximum precooling load (eq.1), it can be seen that $\mathrm{N}_{\max }$ directly affects the maximum precooling load $\left(\mathrm{Q}_{\text {max }}\right)$. The maximum rate of juice supply $\left(\mathrm{N}_{\text {max }}\right)$ as well as the maximum precooling load $\left(\mathrm{Q}_{\max }\right)$ was determined for three different precooling periods; $8 \mathrm{~h}, 12 \mathrm{~h}$ and $16 \mathrm{~h}$ respectively.

\section{8 hour precooling}

When precooling over an $8 \mathrm{~h} /$ day period, say from $09 \mathrm{~h} 00$ to $17 \mathrm{~h} 00$, the rate of juice supply for precooling is assumed to increase steadily until $11 \mathrm{~h} 00$, remain constant until $15 \mathrm{~h} 00$, then decrease steadily until $17 \mathrm{~h} 00$.

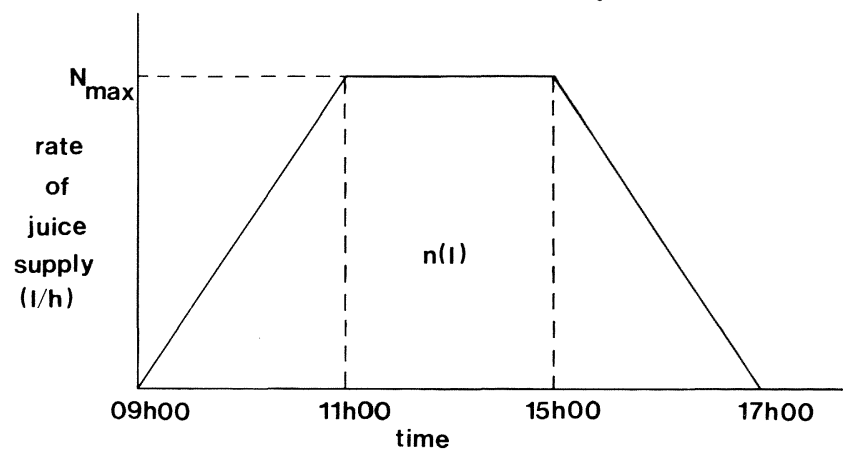

Area below the graph represents daily intake $n$ in $l /$ day, $\mathrm{N}_{\max }$ is the maximum rate of supply.

$\mathrm{n}$ can be calculated using the equation for calculating the area of a trapezium

$$
\begin{aligned}
& \mathrm{n}=\frac{(15.00-11.00)+(17.00-09.00)}{2} \times \mathrm{N}_{\max } \\
\mathrm{N}_{\max }=\frac{\mathrm{n}}{6} l / \mathrm{h} &
\end{aligned}
$$

Therefore,

$\mathrm{Q}_{\max }=$ Maximum precooling load can be calculated as follows

$$
\begin{aligned}
\mathrm{Q}_{\max } & =\mathrm{N}_{\max } \cdot \rho \cdot \mathrm{Cp} \cdot \triangle \mathrm{T} \\
& =\frac{\mathrm{n} l}{6} / \mathrm{h} \times 1.08 \mathrm{~kg} / \mathrm{l} \times 3,64 \mathrm{~kJ} / \mathrm{kgK} \times 9 \mathrm{~K} \\
& =5,897 \mathrm{n} \mathrm{kJ} / \mathrm{h}
\end{aligned}
$$

Similarly it can be shown that for the same period of increasing and decreasing juice supply over precooling periods of $12 \mathrm{~h}$ and $16 \mathrm{~h}$ respectively $\mathrm{Q}_{\max }$ (precooling) changes as follows:

$$
\begin{array}{ll}
\mathrm{Q}_{\max }=3,538 \mathrm{n} \mathrm{kJ} / \mathrm{h} & 12 \mathrm{~h} \text { precooling and } \\
\mathrm{Q}_{\max }=2,527 \mathrm{n} \mathrm{kJ} / \mathrm{h} & 16 \mathrm{~h} \text { precooling. }
\end{array}
$$

Note: $\mathrm{n}$, the daily intake (in litres) can also be calculated as follows:

$\mathrm{n}=$ Maximum daily grape intake $(\mathrm{t}) \mathrm{x}$ litres obtained per metric ton ................................... eq. 2

(In this model it is assumed that $720 l$ of juice recover- 
ed per metric ton has an effect on refrigeration. However, other values may be substituted).

\section{Fermentation load:}

The fermentation load was determined for a fermentation rate of $2^{\circ} \mathrm{B}$ per 24 hours which is equivalent to an overall fermentation period of 11 days for any given batch of juice.

$22^{\circ}$ Balling $=0,238 \mathrm{~kg}$ sugar $/ l($ density of juice $=1,08 \mathrm{~kg} / l)$

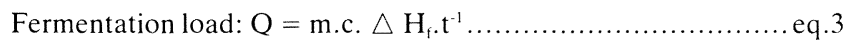

where: $\mathrm{m}=$ holding capacity for fermentation $(l)$

$\mathrm{c}=$ sugar concentration $=0.238 \mathrm{~kg}$ sugar $/ \mathrm{l}$

$\triangle \mathrm{H}_{\mathrm{f}}=$ heat of fermentation $=555 \mathrm{~kJ} / \mathrm{kg}$ sugar

$\mathrm{t}=$ overall fermentation period $=264 \mathrm{~h}\left(11 \mathrm{~d} \times 24 \mathrm{~h} \cdot \mathrm{d}^{-1}\right)$

therefore: $\mathrm{Q}=0,5003 . \mathrm{m} \mathrm{kJ} / \mathrm{h}$

Under maximum fermentation load conditions $m$ can be calculated as follows:

$\mathrm{m}=$ Maximum daily grape intake (in $\mathrm{t}$ ) $\mathrm{x}$ litres obtained per $\mathrm{t} x$ effective crushing time (in days)

$=\mathrm{n} x$ effective crushing time (in days) .........eq. 4

For the purpose of calculating peak load conditions, the effective crushing time can either be a maximum of 11 days (crushing takes place $7 \mathrm{~d}$. week ${ }^{-1}$ ), or a minimum of 9 days (no crushing over weekends).
In the basic model presented in this paper, the effective crushing time cannot exceed 11 days, because on day 12 the juice received on day 1 will have fermented to dryness and, therefore, no longer affect refrigeration. (Overall fermentation period is 11 days).

\section{Heat gain:}

Vergunst (1971) assumed an overall heat gain of $15 \%$. Calculations and actual temperature measurements done at Stellenbosch Farmers Winery (SFW Technical Project $\mathrm{P}(\mathrm{C}) / 40$ - unpublished data) indicate that actual heat gain exceeds $15 \%$.

\section{Fermentation:}

Heat is gained during fermentation through the walls, doors and roof of the building, or through the insulation of the tanks. Calculations done at Stellenbosch Farmers Winery (SFW Technical Project P(C)/40 - unpublished data) indicate that fermentation load is increased by approximately $8-9 \%$ as a result of heat gained. A factor of $10 \%$ is used for the calculations in this paper.

Refrigerated water distribution system:

Heat is gained in the distribution system as well as in both the hot and cold water wells. It is assumed that the

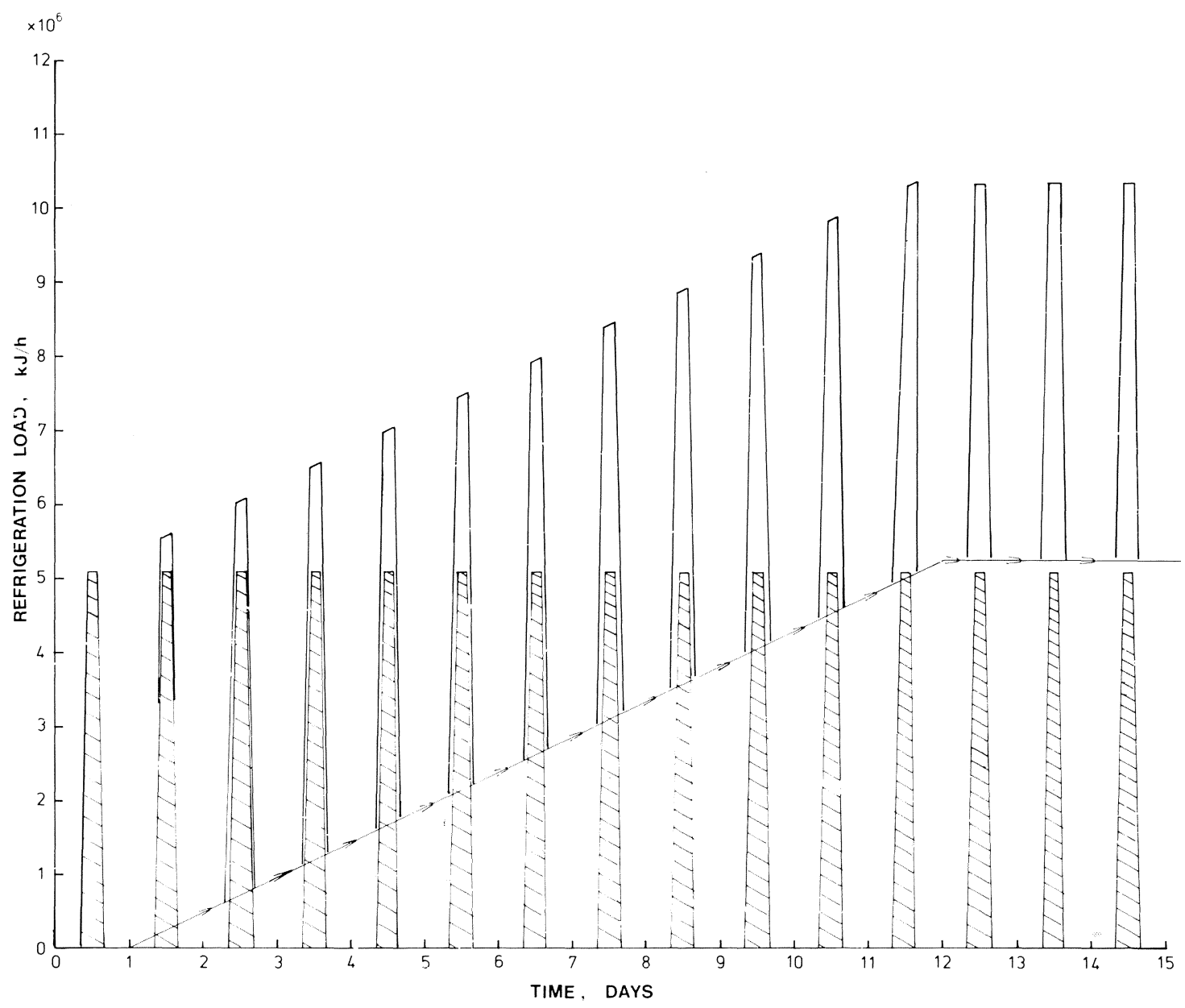

FIG. 2

Refrigeration load for 1000 t of grapes per day precooling for 8 hours.

a) The column of peaks marked with slanted lines represents the daily precooling load.

b) The straight line graph which starts on day 1 and flattens out on day twelve represents the fermentation load.

c) The column of peaks which coincide with the precooling peaks and extend beyond the fermentation load. represents total load. 


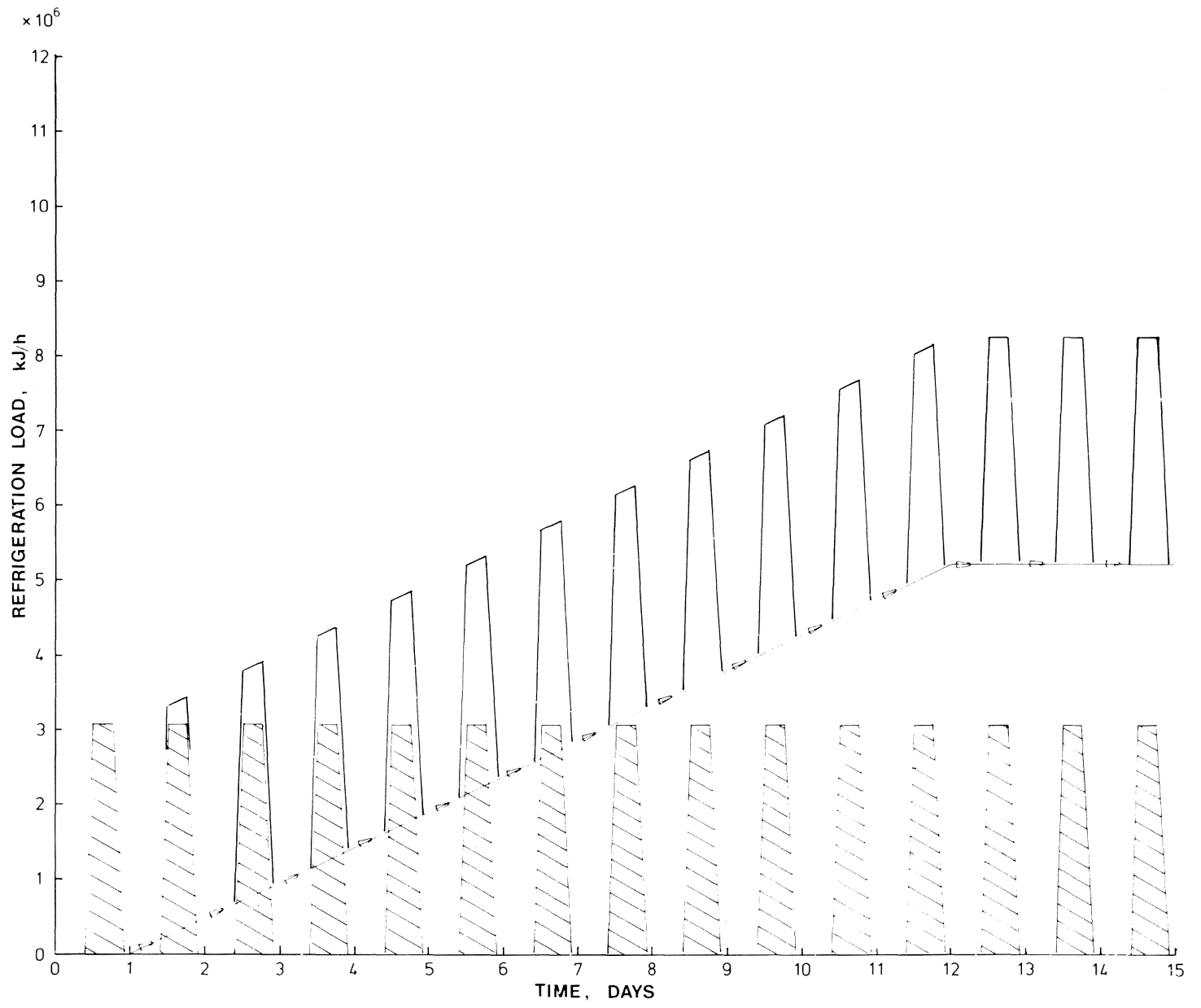

FIG. 3

Refrigeration load for $1000 \mathrm{t}$ of grapes per day, precooling for 12 hours.

a) The column of peaks marked with slanted lines represents the daily precooling load.

b) The straight line graph which starts on day 1 and flattens out on day twelve represents the fermentation load.

c) The column of peaks which coincide with the precooling peaks and extend beyond the fermentation load, represents total load.

refrigerated water system is designed to function between $7^{\circ} \mathrm{C}$ and $13^{\circ} \mathrm{C}$. Therefore, a temperature gain of $1^{\circ} \mathrm{C}$ through the distribution system will represent $\frac{1}{(13-7)}$ or $17 \%$ of the overall refrigeration capacity required. A factor of $20 \%$ is used in this paper.

\section{DISCUSSION}

\section{Summary of maximum refrigeration requirements:}

8 hour precooling period:

Max precooling load:

$5.897 \mathrm{n} \mathrm{kJ} / \mathrm{h}$

where $\mathrm{n}=$ daily intake in $l$

Fermentation load:

$0.5003 \mathrm{~m} \mathrm{~kJ} / \mathrm{h}$

where $\mathrm{m}=$ fermentation holding

capacity $(l)$

Heat gain in building:

$10 \%$ of $0.5003 \mathrm{~m} \mathrm{~kJ} / \mathrm{h}$

Subtotal:

$(5.897 \mathrm{n}+1,1 \times 0,5003 \mathrm{~m}) \mathrm{kJ} / \mathrm{h}$

(i) + (ii) + (iii) $\ldots \ldots \ldots \ldots \ldots \ldots \ldots$ eq. (iv)

Heat gain in refrigerated water distribution system:

$20 \%$ of $(5.897 \mathrm{n}+1.1 \times 0.5003 \mathrm{~m}) \mathrm{kJ} / \mathrm{h} \ldots .(\mathrm{v})$

Therefore, total capacity required is:

$$
1,2(5,897 \mathrm{n}+0,5503 \mathrm{~m}) \mathrm{kJ} / \mathrm{h} \ldots . . \text { (iv) }+(\mathrm{v})
$$

However, refrigeration systems (compressor, condenser, water chiller, etc.) are not $100 \%$ efficient. Assuming the refrigeration system to be $90 \%$ efficient, then the overall refrigeration system design capacity becomes

$\frac{100}{90} \times 1,2(5,897 \mathrm{n}+0,5503 \mathrm{~m}) \mathrm{kJ} / \mathrm{h}$ eq. 5

12 hour precooling period

Max precooling load:

Fermentation load:

Heat gain in building:

Subtotal:

$3.538 . \mathrm{n} \mathrm{kJ} / \mathrm{h}$

$0.5003 . \mathrm{m} \mathrm{kJ} / \mathrm{h}$

Heat gain during distribution:

Total capacity required:

$0.1 \times 0.5003 \mathrm{~m} \mathrm{~kJ} / \mathrm{h}$

$(3.538 \mathrm{n}+1.1 \times 0.5003 \mathrm{~m}) \mathrm{kJ} / \mathrm{h} \ldots$.. eq. (vi)

$\quad 1.2(3.538 \mathrm{n}+0.5503 \mathrm{~m}) \mathrm{kJ} / \mathrm{h}$

Overall design capacity: $\quad 1.33(3.538 \mathrm{n}+0.5503 \mathrm{~m}) \mathrm{kJ} / \mathrm{h}$ .eq.6

\section{6 hour precooling period}

Max precooling load: $\quad 2.527 \mathrm{n} \mathrm{kJ} / \mathrm{h}$

Fermentation load: $\quad 0.5003 \mathrm{~m} \mathrm{~kJ} / \mathrm{h}$

Heat gain in building: $\quad 0.1 \times 0.5003 \mathrm{~m} \mathrm{~kJ} / \mathrm{h}$

Subtotal: $\quad(2.527 \mathrm{n}+1.1 \times 0.5003 \mathrm{~m}) \mathrm{kJ} / \mathrm{h} \ldots$ eq. (vii)

Heat gain during distribution: $0.2(2.527 \mathrm{n}+1.1 \times 0.5003 \mathrm{~m}) \mathrm{kJ} / \mathrm{h}$

Total capacity required: $\quad 1.2(2.527 \mathrm{n}+0.5503 \mathrm{~m}) \mathrm{kJ} / \mathrm{h}$

Overall design capacity: $\quad 1.33(2.527 \mathrm{n}+0.5503 \mathrm{~m}) \mathrm{kJ} / \mathrm{h} \ldots \ldots \ldots$ eq.7

Effect of length of precooling period on overall capa-

city:

Figures 2, 3 and 4 illustrate the effect of spreading the precooling load. If the refrigeration system for a $1000 t$ maximum daily intake is designed for an eight 


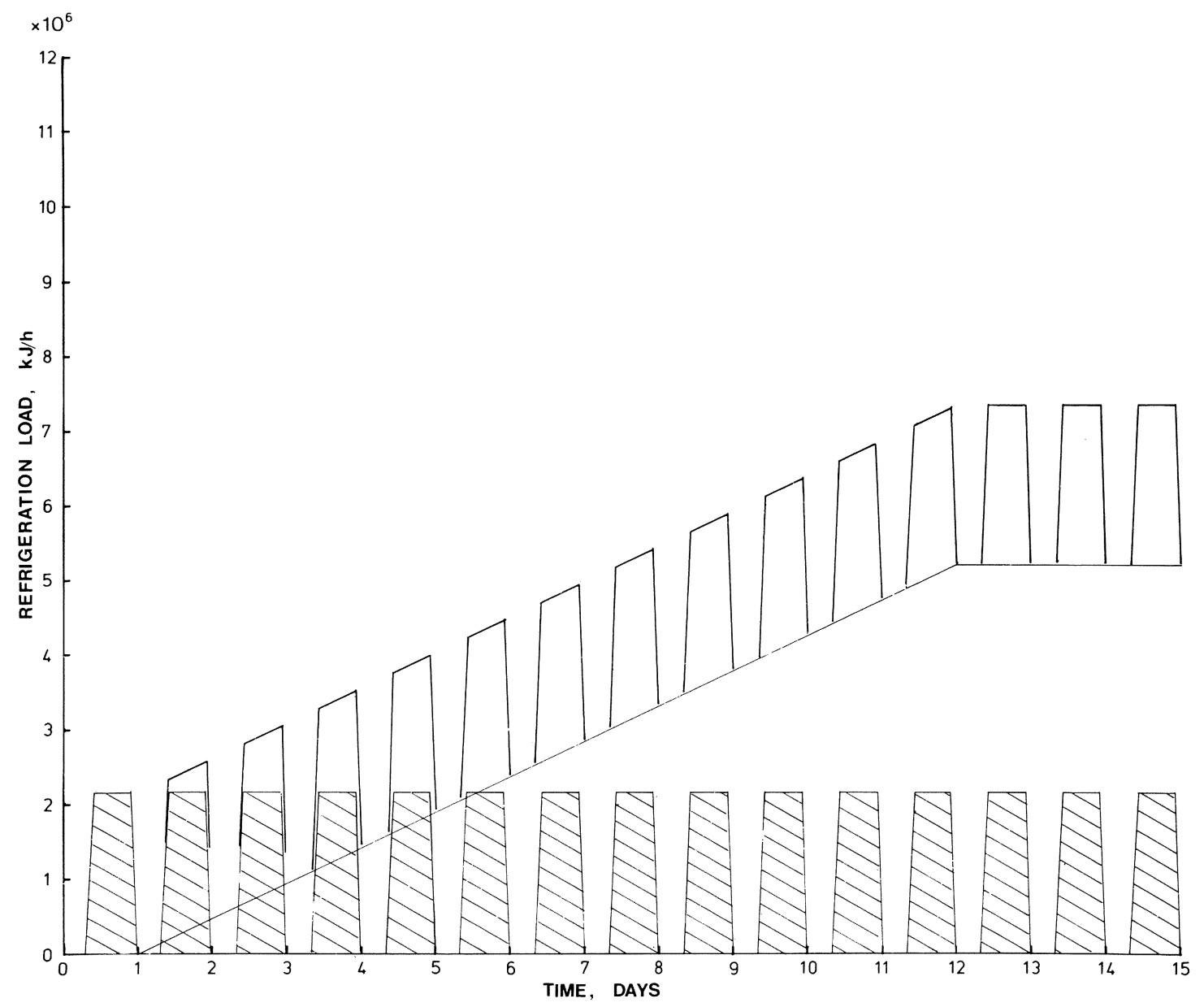

FIG. 4

Refrigeration load for $1000 \mathrm{t}$ of grapes per day, precooling for 16 hours.

a) The column of peaks marked with slanted lines represents the daily precooling load.

b) The straight line graph which starts on day 1 and flattens out on day twelve represents the fermentation load.

c) The column of peaks which coincide with the precooling peaks and extend beyond the fermentation load, represents total load.

hour precooling period (Fig. 2) instead of a sixteen hour precooling period (Fig. 4), the overall design capacity of the refrigeration system must be $40 \%$ greater in order to cope with the increased load.

Approximate refrigeration design capacities for maximum daily intake levels ranging from 10 to $1000 \mathrm{t}$ can be determined from figure 5 for precooling periods of 8,12 and 16 hours respectively.

\section{Effect of temperature of incoming grapes on overall re- frigeration capacity requirements:}

In this paper it is assumed that the average temperature of the grapes received is $22^{\circ} \mathrm{C}$. However, many cellars receive grapes with average temperatures considerably higher than $22^{\circ} \mathrm{C}$.

Figure 6 can be used to calculate the additional refrigeration capacity required to process effectively grapes of which the temperature is higher than $22^{\circ} \mathrm{C}$. The temperature of the grapes received only affect the precooling load. However, for convenience, figure 6 has been adjusted that the effect on the overall design capacity may be determined.

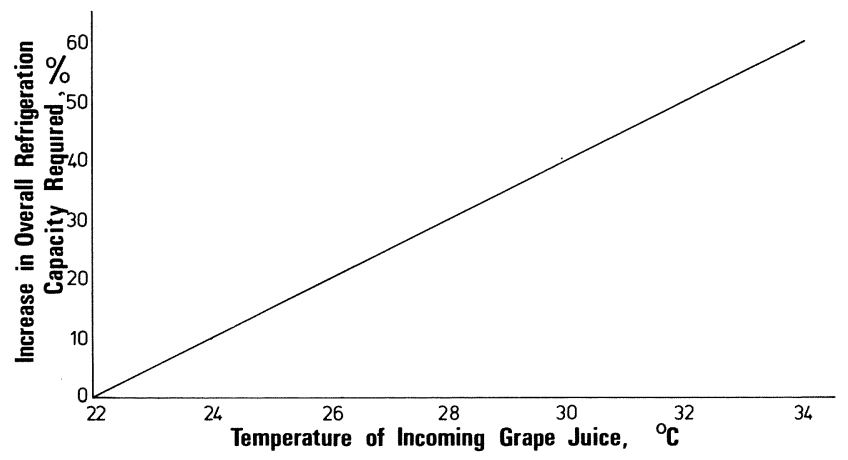

FIG. 6

Effect of heat gain in the refrigerated water distribution system on overall design capacity:

Many refrigerated water distribution systems are not insulated because of the additional cost involved. It is well worth while comparing the cost of insulation with the cost of a larger refrigeration system (plus increased running costs) in order to cope with the heat gain in the distribution system.

In this paper it is assumed that the refrigeration system chills the cooling water to $7^{\circ} \mathrm{C}$ and that the water is returned to the refrigeration system at $13^{\circ} \mathrm{C}$, representing a temperature increase of $6^{\circ} \mathrm{C}$. It is also as- 


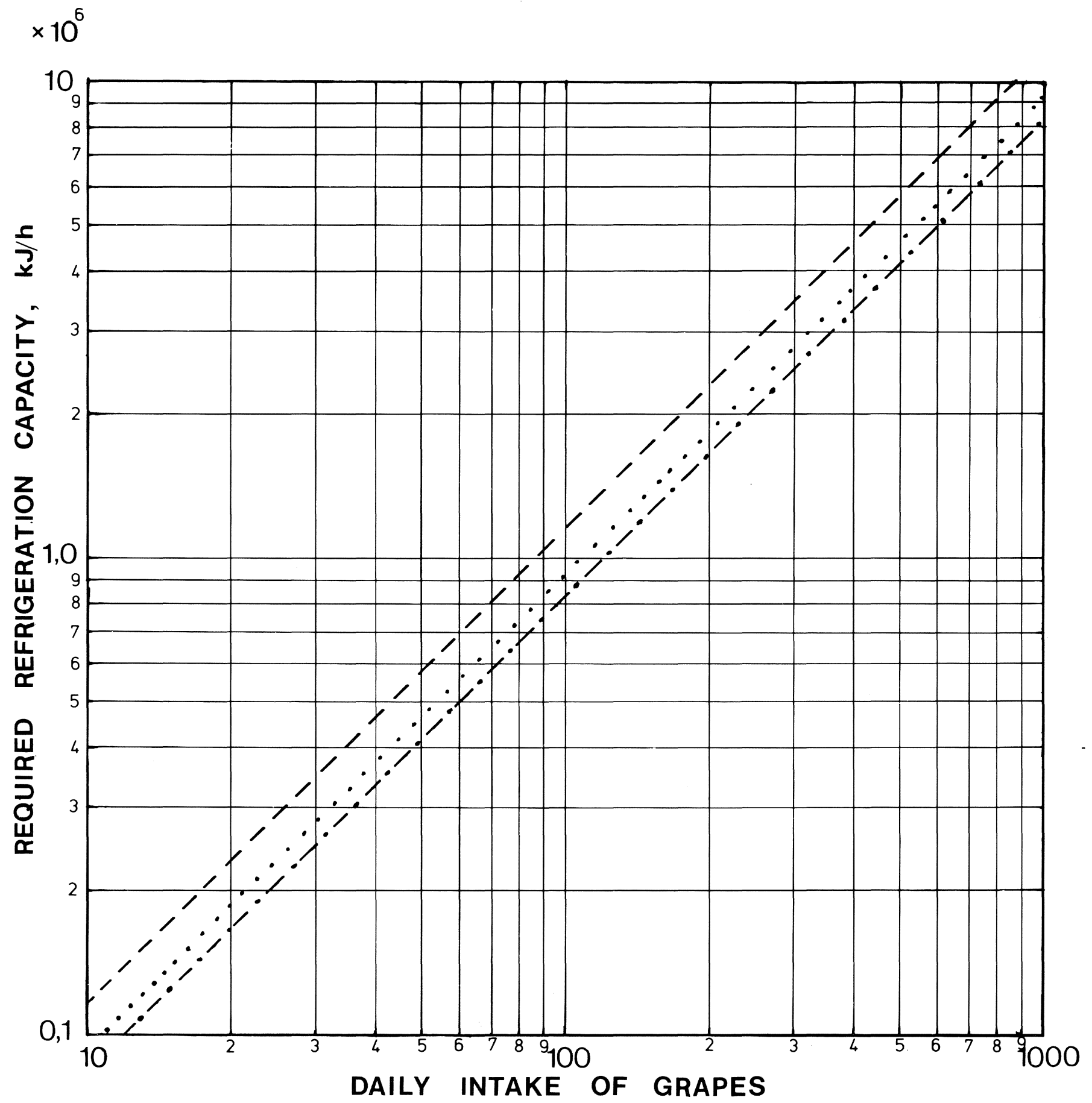

8h Precooling

$12 \mathrm{hPrecooling}$

16h Precooling

FIG. 5

sumed that during distribution of the refrigerated water a temperature increase of $1^{\circ} \mathrm{C}$ occurs. This is equivalent to approximately $20 \%$ of the overall load. Actual temperature measurements (SFW Technical Projects $\mathrm{P}(\mathrm{C}) / 40$ unpublished data) have indicated that in noninsulated distribution systems the temperature increase during distribution may be as high as $3^{\circ} \mathrm{C}$ or $50 \%$ of the overall load.

Figure 7 can be used to calculate the additional re- frigeration capacity required should the gain in temperature in the distribution system exceed $1^{\circ} \mathrm{C}$. (The graph in Fig. 7 can be extrapolated to allow for temperature increases of less than $1^{\circ} \mathrm{C}$. In such an event the overall refrigeration capacity required can be reduced.)

\section{DATABASE APPLICATIONS}

A. Approximation of design capacity:

When designing a refrigeration system for a new cel- 


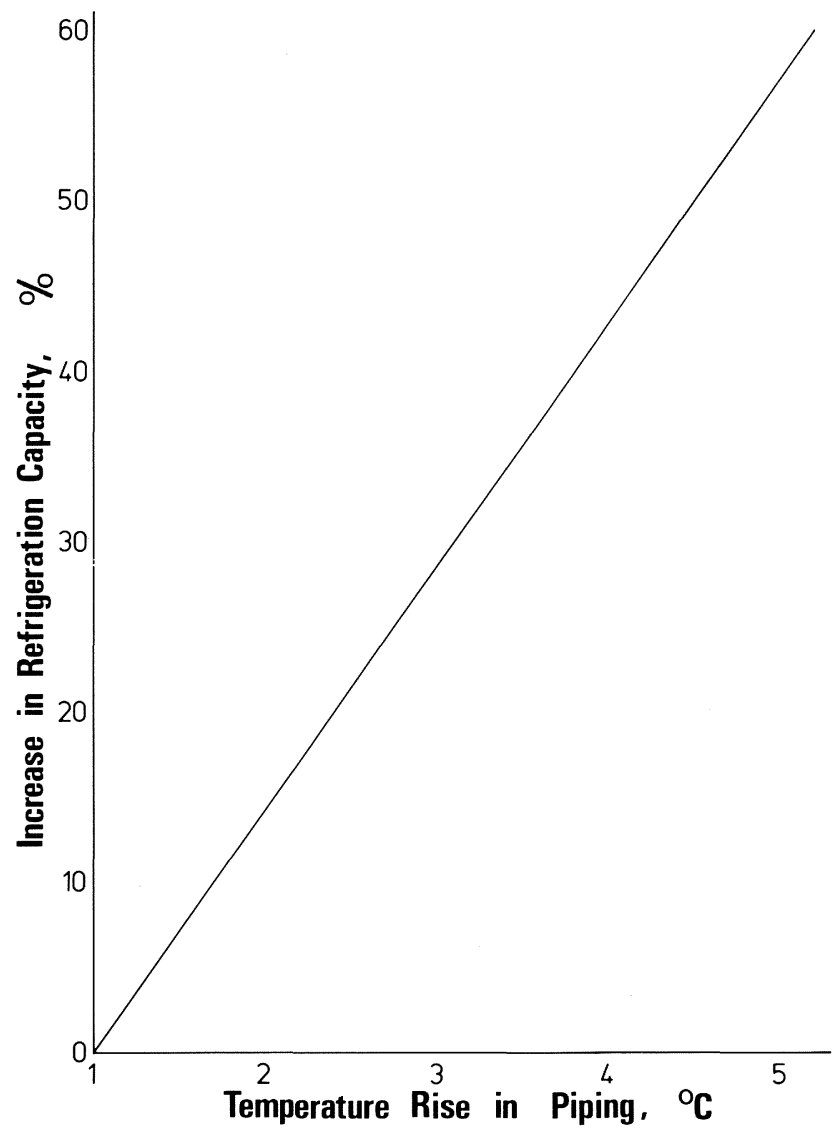

FIG. 7

lar, the following factors must be considered sequentially:

1. What is the expected maximum daily grape intake?

2. Over what period will the precooling load be spread?

(Because we are considering maximum load conditions which usually only occur during a peak period seldom exceeding two to three weeks in a season of approximately $12-14$ weeks, it will probably be the most economical to decide on a sixteen hour precooling period.)

As soon as both questions 1 and 2 have been answered, an approximate design capacity of the refrigeration system can be determined using figure 5 .

3 . What is the average temperature of the grapes received during the peak crushing season?

4. As soon as question 3 has been answered, figure 6 can be used to determine by what percentage the basic design capacity (determined above) must be increased or decreased. (Figure 6 can be extrapolated to allow for temperatures lower than $22^{\circ} \mathrm{C}$.)

Figure 7 can be utilised in conjuction with actual temperature measurements in existing refrigeration systems in order to determine whether or not insulation of the distribution system is a viable proposition.

\section{B. Accurate disign:}

The maximum design capacity can be determined with greater accuracy using equation 7 , in conjunction with equations 2 and 4 .
Maximum design capacity $=1,33(2,527 \mathrm{n}+$

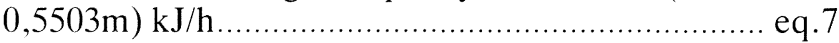
(16h precooling).

The maximum daily intake $(n)=$ Max. daily grape intake $(\mathrm{t}) \times l . \mathrm{t}^{-1}$ (in litres) ................................ eq. 2

The maximum holding capacity $(\mathrm{m})=\mathrm{n} \times$ effective crushing time (in litres) ..................................... eq. 4

For the approximation of capacity, the following factors must be considered sequentially:

1. What is the expected maximum daily grape intake (in $\mathrm{t})$ ?

2. Determine how many litres are to be obtained per metric ton of grapes and calculate $n$ using equation 2.

3. Determine the effective crushing time by determining whether crushing operations will continue for 5 , 6 or 7 days per week. (The effective crushing time can be a maximum of 11 , or a minimum of 9 days).

4. Determine $m$ using equation 4.

5. Substitute the values obtained for $\mathrm{n}$ and $\mathrm{m}$ in equation 7 and determine the basic design capacity.

NOTE: Since we are considering maximum load conditions it will be most economical to design according to a $16 \mathrm{~h}$ precooling period. However, should an eight, or twelve hour precooling period be desired, equations 5 or 6 can be used instead of eq. 7 .

6. Determine the average temperature of the grapes received during the peak crushing season.

7. Use figure 6 to determine by what percentage the basic design capacity (determined in 5 above) must be increased.

\section{Determining maximum daily intake:}

The database can also be used to determine the maximum daily intake capacity of an existing refrigeration system:

1. Obtain the capacity of the refrigeration system from the supplier (in $\mathrm{kJ} / \mathrm{h}$ ).

2. Divide by 1,33

3. Measure the actual heat gain in the cold water distribution system. Use figure 7 to determine by what $\%$ percentage the system capacity (as determined in (2)) must be reduced if the actual heat gain is larger than $1^{\circ} \mathrm{C}$. (If the actual heat gain is less than $1^{\circ} \mathrm{C}$, figure 7 can be extrapolated and the system capacity increased.)

4. Determine the actual maximum temperature of grapes received during the peak season and use figure 6 to determine by what percentage the system capacity (as determined in (3)) should be decreased (for grape temperatures exceeding $22^{\circ} \mathrm{C}$ ) or increased (for grape temperatures lower than $22^{\circ} \mathrm{C}$ ).

5. Determine how many litres are obtained per metric ton of grapes.

6. Determine the effective crushing time. (Refer to the section covering Fermentation load).

7. The maximum daily grape intake for the existing refrigeration plant can now be determined for an eight, twelve or sixteen hour precooling period using any one of equations iv, vi or vii in conjunction with equations 2 and 4.

For a sixteen hour precooling period, the maximum daily intake (in t) can be determined as follows: 
Maximum

intake $=$

(t grapes)

$\frac{\mathrm{Q}}{\begin{array}{l}2,527 .\left(l . \mathrm{t}^{-1}\right)+0,5503 .\left(l \cdot \mathrm{t}^{-1}\right) \cdot(\text { effective } \\ \text { crushing time })\end{array}}$

where $\mathrm{Q}=$

the capacity of the existing plant modified according to steps 2, 3 and 4 .

For a twelve hour precooling period the equation becomes:

Maximum

intake $=$

(t grapes)

$\frac{\mathrm{Q}}{3,538 .\left(l \cdot \mathrm{t}^{-1}\right)+0,5503 \cdot\left(l \cdot \mathrm{t}^{-1}\right) \cdot(\text { effective }}$ crushing time)

and for and eight hour precooling period

Maximum

intake $=$

(t grapes)
When using the data in this paper it is important to remember the assumptions on which it is based. Although this database cannot replace thorough detailed refrigeration design the authors are of the opinion that it provides wine makers with a simple guideline whereby designs can be checked, or the use of the capacity of existing systems managed more efficiently.

\section{LITERATURE CITED}

Vergunst, M.1971. Refrigeration as applied in the Wine Industry. Die Wynboer September 1971 p. 52-55.

SFW Technical Projects. 1985. P(C)/40 Centralising and optimising refrigeration facilities - Preliminary Reports 1 and 2. (SFW Internal Reports). 